\title{
$\beta$-Nerve Growth Factor Levels in Newborn Cord Sera
}

\author{
JOSEPH HADDAD, VÉRONIQUE VILGE, JEAN GEORGES JUIF, MICHEL MAITRE, \\ LIONEL DONATO, JEAN MESSER, AND JEAN MARK \\ Service de Néonatologie [J.H., J.G.J., L.D., J.Me.] and Laboratoire de Biochimie [V.V., M.M., J.Ma.], Hôpital \\ Universitaire de Hautepierre, F 67098 Strasbourg Cedex, France
}

\begin{abstract}
This study was designed to examine $\beta$-nerve growth factor (NGF) levels in human cord blood by a twosite enzyme immunoassay using MAb 27/21 to mouse NGF and to determine whether $\beta$-NGF levels show developmental changes. Blood was collected at delivery from 61 newborns, 55 neonates appropriate for gestational age (46 term infants and 9 premature infants), 5 neonates small for gestational age, and 1 neonate with congenital hydrocephalus. In addition, samples were collected from 2 microcephalic children (microcephaly vera) aged 15 and $18 \mathrm{mo}, 2$ control children, and 4 healthy adults. Mean levels of NGF in preterm infants $(n=9 ; 13.7 \pm 8 \mathrm{pg} / \mathrm{mL})$ were significantly lower than levels in term infants $(n=47 ; 21.2 \pm$ $8.8 \mathrm{pg} / \mathrm{mL} ; p=0.034$ by Mann-Whitney $U$ test). There was no correlation between birth weight, length, head circumference, and $\beta$-NGF levels. In microcephalic children, NGF levels were low $(8 \mathrm{pg} / \mathrm{mL})$ compared with control infants' values $(22 \mathrm{pg} / \mathrm{mL})$. In adults, $\beta$-NGF levels were higher and ranged between 238 and $292 \mathrm{pg} / \mathrm{mL}$. Our study demonstrates that $\beta$-NGF levels can be assessed in human newborn sera using a two-site enzyme immunoassay with MAb 27/21 to mouse $\beta$-NGF, that $\beta$-NGF levels are extremely low in newborns compared with adults, that $\beta$ NGF levels seems to show developmental changes, and that $\beta$-NGF levels may be used to assess NGF utilization under normal and pathologic conditions such as cerebral malformations. (Pediatr Res 35: 637-639, 1994)
\end{abstract}

\section{Abbreviations}

NGF, nerve growth factor

EIA, enzyme immunoassay

Substantial progress has been made in research on nerve swth factors since the initial discovery by Levi Montalcini and Imburger of the first neurotrophin, NGF (1). Apart from NGF, urotrophins include brain-derived neurotrophic factor, neu:rophin 3, neurotrophin 4 , and neurotrophin 5 . They have an portant role in neuronal development and functioning of the rvous system (2). NGF, the best known factor (3), is a complex three subunits $(\alpha, \beta$, and $\gamma)$. The $\beta$ subunit is entirely responle for the biologic effect. It is a dimer of two identical chains 118 amino acids each. The genes for NGF and its receptor ve been cloned and sequenced and are localized on the short $\mathrm{n}$ of human chromosome 1 and the long arm of human romosome 17, respectively. NGF is involved in the establish-

Received July 15, 1993; accepted December 9, 1993.

Correspondence and reprint requests: Joseph Haddad, M.D., Service de Néonlogie, Hòpital Universitaire de Strasbourg, Avenue Molière, F 67098 Strasbourg Jex, France. ment and maintenance of sympathic and neural crest-derived sensory innervation in the periphery and of cholinergic innervation in the CNS $(3,4)$.

$A$ fruitful method in NGF research has been the introduction of a sensitive two-site EIA with MAb $27 / 21$ to mouse $\beta$-NGF that allows reliable determination of low levels of $\beta$-NGF present in peripheral and CNS tissue $(5,6)$. Recently, the two-site EIA was applied to human adult sera and showed low levels of $\beta$ NGF $(0.4 \pm 0.1 \mathrm{ng} / \mathrm{mL})(7)$. The specific objectives of this study were to examine levels of $\beta$-NGF in human cord blood using the two-site EIA with the MAb $27 / 21$ to mouse $\beta$-NGF and to determine whether levels of $\beta$-NGF show developmental changes, as has been reported for $\beta$-NGF in animals (3). During the course of this study, we were also interested in measuring $\beta$ NGF levels in two children with cerebral malformation (microcephaly vera) and comparing their results with those found in the neonatal period and in otherwise healthy children and adults.

\section{MATERIALS AND METHODS}

Subjects. Between October and December 1992, levels of $\beta$ NGF were measured from cord blood in 61 newborn infants. As emphasized above, we included 2 microcephalic children, 2 healthy children considered controls, and 4 healthy adults after obtaining parental and adult consent. This study was approved by our institutional committee for ethics.

Blood samples and pretreatment. Immediately after birth and after clamping the cord, placenta and cord were removed. Then $2.5 \mathrm{~mL}$ of blood were collected by cord puncture. In children and adults, $2.5 \mathrm{~mL}$ of blood were collected by venipuncture while they were at rest.

Blood was collected in nonheparinized tubes containing $50 \mu \mathrm{g}$ of aprotinin. After $1 \mathrm{~h}$ of incubation at room temperature and subsequent incubation at $4^{\circ} \mathrm{C}$ overnight, cells and serum were separated by centrifugation $(20 \mathrm{~min})$. Plasma was stored at $-20^{\circ} \mathrm{C}$ until assay.

$E I A$. A two-site EIA for $\beta$-NGF, slightly modified from that described by Söderstrom $e t$ al. (8), was used for the present study. Immunoplates (black 96-well dishes; Nunc, Roskilde, Denmark) were coated with monoclonal anti-mouse $\beta$-NGF antibody 27/ 21 (obtained from Boehringer Mannheim Biochemica, Mannheim, Germany). The stock solution of purified antibody $27 / 21$ was diluted in $0.05 \mathrm{M}$ carbonate buffer ( $\mathrm{pH} \mathrm{9.6)} \mathrm{to} 0.3 \mu \mathrm{g} / \mathrm{mL}$. Each well received $150 \mu \mathrm{L}$ and the dishes were incubated at $37^{\circ} \mathrm{C}$ for $2 \mathrm{~h}$. After washing them three times with wash buffer (Tris$\mathrm{HCl}, 50 \mathrm{mmol} / \mathrm{L} ; \mathrm{NaCl}, 200 \mathrm{mmol} / \mathrm{L} ; \mathrm{CaCl}_{2}, 10 \mathrm{mmol} / \mathrm{L}$; Triton $\mathrm{X}-100,0.1 \%$; sodium azide, $0.05 \%$; $\mathrm{pH} 7.0$ ), the samples were applied in a volume of $100 \mu \mathrm{L}$, and the plates were sealed and incubated overnight at $4^{\circ} \mathrm{C}$. To serve as standards, samples of purified mouse $\beta$-NGF at $10-1000 \mathrm{pg} / \mathrm{mL}$ in the same buffer were also included.

The plates were then washed three times in wash buffer at room temperature before antibody $27 / 21 \beta$-galactosidase conju- 
gate (Boehringer Mannheim Biochemica; $4 \mathrm{U}$ of enzyme activity $/ \mathrm{mL})$ was added $(100 \mu \mathrm{L})$ at a dilution of $1: 50$ in sample buffer and incubated at $37^{\circ} \mathrm{C}$ for $4 \mathrm{~h}$.

After incubation, the immunoplates were washed three times with wash buffer. To start the enzyme activity, $200 \mu \mathrm{L}$ of chlorophenol red $\beta$-D-galactopyranoside diluted $(2 \mathrm{mg} / \mathrm{mL})$ in a substrate buffer [ $N$-2-hydroxyethylpiperazine- $N^{\prime}-2$-ethanesulfonic acid, $100 \mathrm{mmol} / \mathrm{L} ; \mathrm{NaCl}, 150 \mathrm{mmol} / \mathrm{L} ; \mathrm{MgCl}_{2}, 2 \mathrm{mmol} /$ L; sodium azide, $0.1 \%$ (wt/vol); albumin, $1 \%$ (wt/vol); $\mathrm{pH} 7.0$ ] were added to each well and incubated for $2 \mathrm{~h}$ at room temperature.

Each immunoplate was introduced in a spectrophotometer (emission wavelength $570 \mathrm{~nm}$ ). The EIA values for serum samples were determined from the regression line for the NGF standard incubated under similar conditions.

EIA calibration. The EIA calibration was performed according to blood samples drawn from either neonates, children, or adults. Standard samples of purified mouse NGF (NGF 2.5 S, Boehringer Mannheim Biochemica) were incubated under conditions similar to those of blood samples. When blood samples from neonates or children were examined by the two-site EIA, samples of purified mouse NGF at concentrations of $2,5,10,20$, and $100 \mathrm{pg} / \mathrm{mL}$ were used; for adults, samples of $20,50,100,200$, 300,400 , and $500 \mathrm{pg} / \mathrm{mL}$ were used. As shown in Figure 1, the dose-response curve for the standard purified mouse NGF showed a linear relationship. Thus, the sensitivity of this two-site EIA under these conditions was routinely approximately $2 \mathrm{pg} /$ $\mathrm{mL}$ and is similar to that reported by Söderstrom $\mathrm{et}$ al. (8).

Statistical analysis. The significance of the difference between means was determined by Mann-Whitney U Test and the correlation was determined by Pearson's method and multiple regression analysis.

\section{RESULTS}

$\beta$-NGF levels are reported for newborn infants, infants, and adults in Table 1.

Newborn Infants. Among the 61 infants included in this study, 55 were appropriate for gestational age and 5 were small for gestational age according to Lubchenco curves of fetal growth. One infant showed congenital hydrocephalus.

Appropriate for gestational age $(n=55)$. Nine infants were premature, with a mean gestational age \pm SD of $32 \pm 4$ wk (26$36 \mathrm{wk}$ ), mean birth weight \pm SD of $2150 \pm 1033 \mathrm{~g}$, mean birth length $\pm S D$ of $43.22 \pm 6.22 \mathrm{~cm}$, and mean head circumference $\pm \mathrm{SD}$ of $30.8 \pm 3 \mathrm{~cm}$.

Forty-six infants were born at term, with a mean gestational

Optic density

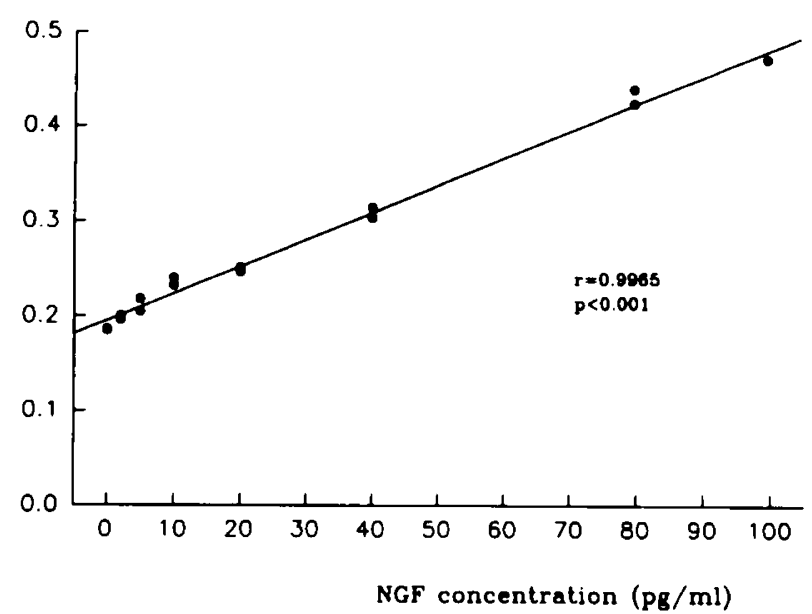

Fig. 1. EIA calibration: Dose-response curve from the standard purified mouse. A linear relationship is evident. The detection limit for the NGF was routinely approximately $2 \mathrm{pg} / \mathrm{mL}$. age \pm SD of $39.22 \pm 1.33$ wk; mean birth weight \pm SD of 3371 $\pm 516 \mathrm{~g}$, mean birth length \pm SD of $49.9 \pm 2 \mathrm{~cm}$, and mean head circumference \pm SD of $34.4 \pm 1.4 \mathrm{~cm}$.

All infants had an Apgar score greater than 7 at $5 \mathrm{~min}$. No cerebral or other congenital malformations were noted in this group of infants.

Mean levels of $\beta$-NGF in preterm infants $(13.7 \pm 8 \mathrm{pg} / \mathrm{mL})$ were significantly lower than those in term infants $(21.2 \pm 8 \mathrm{pg} /$ $\mathrm{mL})(p=0.034$ by Mann-Whitney U test). When serum levels of $\beta$-NGF were plotted against gestational age, birth weight, birth length, and head circumference, no correlations were seen.

Small for gestational age $(n=5)$. Five term neonates ( $40 \mathrm{wk}$ gestational age) rated as symmetric intrauterine growth retarded according to Lubchenco curves of fetal growth were included in this study. Their mean gestational age \pm SD was $38 \pm 1$ wk, mean birth weight \pm SD $1934 \pm 314 \mathrm{~g}$, mean birth length 43.2 $\pm 2 \mathrm{~cm}$, and mean head circumference \pm SD $29.6 \pm 1 \mathrm{~cm}$. Their mean $\beta$-NGF level was $16.08 \pm 5 \mathrm{pg} / \mathrm{mL}(8.70-28.20 \mathrm{pg} / \mathrm{mL})$, which was comparable to the values reported for infants appropriate for gestational age.

Congenital hydrocephalus. In one neonate, prenatal cerebral ultrasound showed dilated lateral and third ventricles. At birth ( 37 wk gestation), head circumference was $38.5 \mathrm{~cm}$, weight was $3080 \mathrm{~g}$, and length was $50 \mathrm{~cm}$. Magnetic resonance imaging showed stenosis at the level of the sylvian aqueduct. The $\beta$-NGF level was $2.28 \mathrm{pg} / \mathrm{mL}$.

Infants. Two children, aged 15 and $18 \mathrm{mo}$, were severely microcephalic (36.9 and $40.5 \mathrm{~cm}$, respectively). Microcephaly was determined to be "microcephaly vera." On magnetic resonance images, no cerebral lesions or cerebral malformations other than microcephaly were noted. $\beta$-NGF levels were 8 and 9 $\mathrm{pg} / \mathrm{mL}$ for the 15 -mo-old and the 18 -mo-old, respectively.

The two other children, aged 14 and $16 \mathrm{mo}$, included were admitted to our unit for a mild respiratory disease. Their weight, length, and head circumference were within the normal ranges. $\beta$-NGF levels were 20.68 and $23.82 \mathrm{pg} / \mathrm{mL}$ for the 14 -mo-old and the 16-mo-old, respectively.

Adults. The four adults included in this study were from the medical staff of the unit and were healthy. Their recorded $\beta$ NGF levels were as high as $292 \mathrm{pg} / \mathrm{mL}$.

\section{DISCUSSION}

$\beta$-NGF from humans and mice have been characterized and found to be highly homologous (8). Each monomer of both types is composed of 118 amino acids, but the amino acid sequence differs (8). Until recently, because of the similarity between human and mouse NGF, MAb 27/21 to mouse $\beta$-NGF has been used in a two-site EIA to detect human NGF from various tissues (5-8). However, with the advent of new recombinant human anti-NGF, the detection of $\beta$-NGF, especially at low levels, seems to be more reliable (9). Nevertheless, the EIA performed at two sites using MAb 27/21 has proved to be highly sensitive, allowing detection of NGF concentrations as low as 0.5 to $2.5 \mathrm{pg} / \mathrm{mL}(7)$. Söderstrom et al. (8) demonstrated the ability of the two-site EIA using MAb 27/21 to detect human NGF at the same sensitivity as mouse NGF. Furthermore, they demonstrated that MAb $27 / 21$ to mouse $\beta$-NGF was highly effective in blocking the biologic activity of both mouse and human recombinant NGF. It is worth mentioning that the two-site EIA used in our study does not differ significantly from that used by Söderstrom et al., especially regarding incubation and washing procedures on which the high sensitivity of the EIA relies (8).

Using the two-site EIA with antibody $27 / 21$ to mouse $\beta$-NGF, we were able to detect very low levels of $\beta$-NGF in human neonatal cord blood compared with adult blood; our values in adults were comparable to those reported by Loragidos et al. (7). However, the presence of trace amounts of $\beta$-NGF in serum of neonates is unlikely to be of physiologic relevance. The serum levels of $\beta$-NGF probably reflect diffusion from target areas for 
Table 1. $\beta$-NGF levels in cord blood sera of newborn infants and in sera of infants and adults*

\begin{tabular}{|c|c|c|c|c|c|c|c|}
\hline & \multicolumn{4}{|c|}{ Newborn infants $(n=61)$} & \multicolumn{2}{|c|}{ Infants $(n=4)$} & \multirow[b]{3}{*}{ Adults $(n=2)$} \\
\hline & \multicolumn{2}{|c|}{$\mathrm{AGA}(n=55)$} & \multirow{2}{*}{$\begin{array}{c}\mathrm{SGA}(n=5) \\
(\text { term })\end{array}$} & \multirow{2}{*}{$\begin{array}{c}\mathrm{CH}(n=1) \\
\text { (term) }\end{array}$} & \multirow{2}{*}{$\begin{array}{c}\text { Microcephaly } \\
\text { vera }\end{array}$} & \multirow{2}{*}{$\begin{array}{c}\text { Reference } \\
\text { infants }\end{array}$} & \\
\hline & Premature & Term & & & & & \\
\hline$n$ & 9 & 46 & 5 & 1 & 2 & 2 & \\
\hline Age & $32 \pm 4$ WGA & $39 \pm 22 \mathrm{WGA}$ & $38 \pm 1$ WGA & 37 WGA & 15 and $18 \mathrm{mo}$ & 14 and $16 \mathrm{mo}$ & $\begin{array}{c}24,25,36 \\
\text { and } 37 \mathrm{y}\end{array}$ \\
\hline$\beta$-NGF $(\mathrm{pg} / \mathrm{mL})$ & $13.7 \pm 8$ & $21.2 \pm 8 \dagger$ & $16.08 \pm 5$ & 2.28 & 8 and 9 & 20.68 and 23.82 & $\begin{array}{l}238,265,288, \\
\text { and } 292\end{array}$ \\
\hline
\end{tabular}

* AGA, appropriate for gestational age; SGA, small for gestational age; $\mathrm{CH}$, congenital hydrocephalus; WGA, weeks of gestational age.

$+p=0.034$ (Mann-Whitney U test).

innervation or release of NGF from other possible sources in the human body. Thus, the low levels of $\beta$-NGF encountered in neonates may be caused by the low diffusion to the serum compartment. An alternative explanation would be interfering protein binding. However, the specificity of MAb $27 / 21$ to $\beta$ NGF is well documented and there is no cross-reactivity with other growth factors such as brain-derived neurotrophic factor, neurotrophins, epidermal growth factor, fibroblast growth factor, or insulin (7). Thus, the immunoreactivity in human serum established by the two-site EIA with MAb 27/21 more likely accounts for NGF

The detection of $\beta$-NGF in premature infants suggests that NGF is present during prenatal life. Indeed, other investigators have reported the detection of NGF mRNA and its complete nucleotide sequence in human fetal brain (cortices) as early as $15 \mathrm{wk}$ of gestation and suggested that the trophic agent may play a role in cerebral development $(10,11)$. NGF has also been detected in human amniotic fluid (12) and human placenta (13). The difference noted in our study between levels of $\beta$-NGF in preterm and term infants and adults suggests a developmental appearance of NGF in humans, as has been described in the brain of animals (3). However, the difference noted between levels of preterm and term infants, although statistically significant, may be subject to discussion because it considers a small group of infants. It is noteworthy that infants with cerebral malformations (congenital hydrocephalus and microcephaly) showed the lowest values of $\beta$-NGF. However, because of the small number of subjects, such data are difficult to interpret. Nevertheless, the low values encountered in those infants suggest reduced NGF activity or NGF utilization in association with reduced cerebral parenchyma. The same findings of low levels of $\beta$-NGF were reported in adult patients suffering from Parkinson's and Alzheimer's diseases (7).

In conclusion, our study demonstrates that $\beta$-NGF levels can be detected in human newborn sera using a two-site EIA with MAb $27 / 21$ to mouse $\beta$-NGF; that these $\beta$-NGF levels are extremely low in newborns compared with adults; that $\beta$-NGF levels in sera seem to show developmental changes; and that $\beta$ NGF levels may be used to assess NGF utilization under normal and pathologic conditions such as cerebral malformations. However, more studies are warranted to assess the developmental changes of NGF levels and to confirm our data.

Acknowledgment. The authors thank Professor Ted Ebendal (Uppsala Unversitet, Department of Developmental Biology) for his advice in editing this manuscript.

\section{REFERENCES}

1. Levi Montalcini R 1987 The nerve growth factor 35 years later. Science 237:1154-1161

2. Barde YA 1990 The nerve growth factor family. Prog Growth Factor Res 2:237-248

3. Ebendal T 1989 NGF in CNS: experimental data and clinical implications. Prog Growth Factor Res 1:143-159

4. Thoenen H, Bandtlow C, Heumann R 1987 The physiological function of NGF in the central nervous system: comparison with periphery. Rev Physiol Biochem Pharmacol 109:145-178

5. Lärfkors L, Ebendal T 1987 Highly sensitive enzyme immunoassays for $\beta$ NGF. J Immunol Methods 97:41-47

6. Korsching S, Thoenen H 1987 Two site enzyme immunoassay for NGF Methods Enzymol 147:167-185

7. Loragidos L, Söderstrom S, Ebendal T 1992 Two site enzyme immunoassay for $\beta$ NGF applied to human patient sera. J Neurosci Res 32:329-339

8. Söderstrom S, Hallbook F, Ibanez CF, Persson H, Ebendal T 1990 Recombinant human $\beta$ NGF: biological activity and properties in an enzyme immunoassay. J Neurosci Res 27:665-677

9. Murase K, Furakawa Y, Iwane M, Hayashi K 1991 Development of sensitive enzyme immunoassay for human nerve growth factor. Biochem Int 25: 29-34

10. Pizutti A, Borsani G, Falini A, Rugarli E, Sidoli A, Baralle F, Scartato G, Silani $V 1990$ Detection of $\beta$ NGF mRNA in the human fetal brain. Brain Res 518:337-341

11. Borsani G, Pizutti A, Rugarli E, Falini A, Scarlato G, Baeralle F, Silani V 1991 Human fetal brain $\beta$ NGF cDNA: molecular cloning of 5 ' and $3^{\prime}$ untranslated regions. Neurosci Lett 127:117-120

12. Kaisain MT, Neet KE $1989 \mathrm{NGF}$ in human amniotic fluid and cerebrospinal fluid. Biofactors 2:99-104

13. Heinreich G, Meyer T 1988 NGF is present in human placenta and serum but undetectable in normal and Paget's disease blood: measurements with an antimouse NGF enzyme immunoassay using a recombinant human NGF reference. Biochem Biophys Res Commun 155:482-486 